\title{
Evaporation or serpentinization? Origin of the Cretaceous South Atlantic salt
} giant

\author{
P. Szatmari ${ }^{1 *}$, C. Rigoti ${ }^{2}$, C. More Lima ${ }^{3}$, G.T. \\ Fontaneta $^{4}$, N.M. Lima ${ }^{5}$, E. Zambonato ${ }^{6}$, J. \\ Bahniuk $^{7}$, S.A.A. Lima Coelho ${ }^{8}$, M.F. Figueiredo ${ }^{9}$, \\ C. Florêncio ${ }^{10}$, M.R.F. Menezes ${ }^{11}$, R.C. Gontijo ${ }^{12}$. \\ 123
}

${ }^{1}$ szatmari@petrobras.com.br 2rigoti@; ${ }^{3}$ claudia_lima@; ${ }^{4}$ gabriella.fontaneta@; 5neilma.lima@; ${ }^{-}$eveline.zambonato@ 7jubahniuk@, ${ }^{8}$ saalima@; ${ }^{9}$ milenefigueiredo@; ${ }^{10}$ cpirescpf@; ${ }^{11}$ rosimenezes@ ${ }^{11}$ rgontijo@ 1-12@petrobras.com.br Petrobras, Rio de Janeiro, Brazil

The South Atlantic salt giant, the world's largest extant body of salt, deposited near the Aptian/Albian boundary at $110.64 \pm 0.34 \mathrm{Ma}$ according to $39 \mathrm{Ar} / 40 \mathrm{Ar}$ analysis in sylvinite. It extends for about $2200 \mathrm{~km}$ from onland Sergipe to the offshore Santos basin where it provides the seal of a giant oil province of over 50 billion bbl in place. Salt deposition was cyclic, with carnallite, sylvinite, bischoffite and tachyhydrite occurring in Sergipe and Santos basins near the northern and southern ends of the salt body, but not in between, in the Campos and Espírito Santo basins. Seismic and gravimetric studies identified intense serpentinization of the hyperextended lithosphere. Did the salt deposit by evaporation of a giant brine lake, formed by seawater entering over the volcanic protoWalvis Ride in the south and through pull-apart rifts between Brazil and NW-Africa along intracontinental equatorial strike slip faults in the north, mixed with terrestrial runoff and hydrothermal brines, or was the water consumed by peridotite hydration? We attempt to answer with macroscopic and microscopic petrography and geochemistry of continuously cored wells in the salt. We give particular attention to seasonal lamination, crystal growth, crystalloblasts and mylonitization. 